\title{
The Human Cytomegalovirus US28 Protein Is Located in Endocytic Vesicles and Undergoes Constitutive Endocytosis and Recycling
}

\author{
Alberto Fraile-Ramos, ${ }^{*}$ Thomas N. Kledal, ${ }^{+\ddagger}$ Annegret Pelchen-Matthews, ${ }^{*}$ \\ Katherine Bowers, ${ }^{*}$ Thue W. Schwartz, ${ }^{+}$and Mark Marsh ${ }^{*}$
}

*Medical Research Council Laboratory for Molecular Cell Biology and Department of Biochemistry,
University College London, London WC1E 6BT, United Kingdom; and ‡Laboratory for Molecular
Pharmacology, The Panum Institute, University of Copenhagen, DK-2200 Copenhagen, Denmark

Submitted December 20, 2000; Revised March 13, 2001; Accepted March 14, 2001

Monitoring Editor: Howard Riezman

\begin{abstract}
Genes encoding chemokine receptor-like proteins have been found in herpes and poxviruses and implicated in viral pathogenesis. Here we describe the cellular distribution and trafficking of a human cytomegalovirus (HCMV) chemokine receptor encoded by the US28 gene, after transient and stable expression in transfected HeLa and Cos cells. Immunofluorescence staining indicated that this viral protein accumulated intracellularly in vesicular structures in the perinuclear region of the cell and showed overlap with markers for endocytic organelles. By immunogold electron microscopy US28 was seen mostly to localize to multivesicular endosomes. A minor portion of the protein (at most 20\%) was also expressed at the cell surface. Antibody-feeding experiments indicated that cell surface US28 undergoes constitutive ligand-independent endocytosis. Biochemical analysis with the use of iodinated ligands showed that US28 was rapidly internalized. The high-affinity ligand of US28, the $\mathrm{CX}_{3} \mathrm{C}$-chemokine fractalkine, reduced the steady-state levels of US28 at the cell surface, apparently by inhibiting the recycling of internalized receptor. Endocytosis and cycling of HCMV US28 could play a role in the sequestration of host chemokines, thereby modulating antiviral immune responses. In addition, the distribution of US28 mainly on endosomal membranes may allow it to be incorporated into the viral envelope during HCMV assembly.
\end{abstract}

\section{INTRODUCTION}

Chemokine receptors are a subgroup of the superfamily of seven transmembrane domain (7TM) G-protein-coupled receptors (GPCRs) that bind inflammatory chemokines and regulate leukocyte migration (Murphy et al., 2000). Open reading frames (ORFs) with the potential to encode 7TM

\footnotetext{
‡ Present address: Department of Microbiology and Immunology, Stanford University School of Medicine, Stanford, CA 943055124.

$\$$ Corresponding author. E-mail address: m.marsh@ucl.ac.uk. Abbreviations used: BM, binding medium; CCR5, CC-chemokine receptor 5; $\mathrm{CHO}$, Chinese hamster ovary; CXCR4, CXC chemokine receptor 4; DARC, Duffy antigen receptor for chemokines; EM, electron microscopy; FCS, fetal calf serum; GFP, green fluorescent protein; GPCR, G-protein coupled receptor; HA, hemagglutinin; HCMV, human cytomegalovirus; HRP, horseradish peroxidase; Ig, immunoglobulin; ORF, open reading frame; PBS, phosphate-buffered saline; RANTES, regulated on activation normal $\mathrm{T}$ cell expressed and secreted; SDF-1, stromal cell-derived factor 1; 7TM, seven-transmembrane domain; YFP, yellow fluorescent protein.
}

proteins with features similar to chemokine receptors have been identified in the genomes of herpes and poxviruses. Some of these genes have been implicated in pathogenesis and the proteins demonstrated to bind chemokines (Ahuja and Murphy, 1993; Neote et al., 1993; Cesarman et al., 1996; Arvanitakis et al., 1997; Isegawa et al., 1998; Kledal et al., 1998; Milne et al., 2000). The genome of human cytomegalovirus (HCMV) contains four ORFs encoding putative 7TM chemokine receptor UL33, UL78, US27, and US28 (Chee et al., 1990; Gompels et al., 1995). Although the proteins encoded by these genes are not required for HCMV replication in culture (Mocarski and Kemble, 1996), their importance for virus persistence in vivo has been suggested by gene deletion experiments in related viruses. Mouse and rat CMVs that lack the homologue of HMCV UL33 (M33 and R33, respectively) are unable to replicate in salivary glands and their dissemination is compromised in the host populations (Davis-Poynter et al., 1997; Beisser et al., 1998).

Although important, little is known about the properties of the HCMV 7TM proteins. As yet only US28 has been characterized pharmacologically. This protein binds with 
high affinity to several CC-chemokines such as macrophage inflammatory polypeptide (MIP)- $1 \alpha$, MIP- $1 \beta$, monocyte chemotactic protein (MCP)-1, and regulated on activation normal T cell expressed and secreted (RANTES) (Neote et al., 1993; Gao and Murphy, 1994; Kuhn et al., 1995) as well as the $\mathrm{CX}_{3} \mathrm{C}$-chemokine fractalkine (Kledal et al., 1998). At the cellular level, HCMV infection induces cellular changes, some of which are associated with G-protein signaling (Albrecht et al., 1990). Signal transduction through US28 has been observed as a transient increase in intracellular calcium in response to high CC-chemokine concentrations (Gao and Murphy, 1994; Vieira et al., 1998) and as an activation of the mitogen-activated protein kinase pathway in response to RANTES (Billstrom et al., 1998). Furthermore, expression of US28 induces migration of smooth muscle cells in response to RANTES and MCP-1, implicating HCMV in the pathogenesis of atherosclerosis and restenosis (Streblow et al., 1999). Recently it was shown that US28 displays constitutive signaling activity that can be modulated in part by fractalkine (Casarosa et al., 2001; T. Kledal and T. Schwartz, unpublished data).

In addition to signaling activities, the 7TM proteins of HCMV have also been implicated in immune system evasion. HCMV has developed a number of strategies to escape immune surveillance and to persist in the host after primary infection. These include down-regulation of major histocompatibility complex class I molecules from the cell surface (Grulher and Früh, 2000). Recently it was suggested that the ability of US28 to bind and sequester cellular chemokines from the environment around HCMV-infected cells may also be a strategy to evade the immune system (Bodaghi et al., 1998; Vieira et al., 1998).

In the present study we examined the cellular distribution and trafficking of the HCMV chemokine receptor US28. In contrast to most cellular chemokine receptors that are expressed at the cell surface, we found that US28 was mostly located intracellularly in perinuclear endosomes. Interestingly, previous studies have indicated that HCMV particles complete their assembly and obtain their final envelope by budding into endosomal compartments (Smith and De Harven, 1973; Tooze et al., 1993). Thus, association of US28 with endosomal organelles may facilitate its incorporation into the viral membrane during HCMV assembly. We also found that US28 undergoes rapid constitutive agonist-independent endocytosis, similar to that of activated chemokine receptors, and that the internalized receptors can recycle to the cell surface. This constitutive endocytosis and cycling may play a role in the sequestration of chemokines from the milieu around HCMV-infected cells (Bodaghi et al., 1998; Vieira et al., 1998).

\section{MATERIALS AND METHODS}

\section{Reagents}

Tissue culture reagents and Nunc tissue culture plastic were from Life Technologies (Paisley, UK), and other chemicals were from Sigma Aldrich (Poole, UK), unless otherwise indicated. Radioactive reagents were from Amersham Pharmacia Biotech (Little Chalfont, UK). Recombinant RANTES (Proudfoot et al., 1996) was provided by Dr. Amanda Proudfoot (Serono Pharmaceutical Research Institute SA, Geneva, Switzerland), and recombinant stromal cell-derived factor $1 \alpha$ (SDF-1 $\alpha$ ) was provided by Dr. Mike Luther (Glaxo Wellcome, Research Triangle Park, NC). The chemokine domain corresponding to amino acid 1 through 69 of the $\mathrm{CX}_{3} \mathrm{C}$-chemokine fractalkine and the cDNA encoding the US28 chemokine receptor from HCMV Towne strain (GenBank accession number P09704) were provided by Dr. Timothy Wells (Serono Pharmaceutical Research Institute).

\section{Receptor Constructs}

The US28 cDNA was inserted into the pEGFP-N1 expression vector (Clontech Laboratories, Palo Alto, CA) with the use of cohesive end ligation. Fusion proteins of the receptor with the yellow fluorescent protein (YFP), the $2 \mathrm{~N}$-terminal immunoglobulin (Ig) domains of CD4 or a hemagglutinin (HA)-tag (the epitope YPYDVPDYA from the influenza virus HA) were generated with the use of polymerase chain reaction and inserted into the PTEJ8 expression vector (Johansen et al., 1990). All receptor constructs were confirmed by sequencing.

\section{Antibodies}

Antibodies used in this study were as follows: anti-CD4, Q4120 (Healey et al., 1990) was obtained from the AIDS Reagent Project of the United Kingdom Medical Research Council (Potters Bar, UK); anti-CXC chemokine receptor 4 (CXCR4), 12G5 (Endres et al., 1996) was provided by Dr. James Hoxie (University of Pennsylvania, Philadelphia, PA); anti-CC chemokine receptor 5 (CCR5), MC-5 (Signoret et al., 2000) was provided by Dr. Matthias Mack (Medizinische Poliklinik, Ludwig-Maximilians-University of Munich, Munich, Germany); anti-HA, 12CA5 was provided by Dr. David Drechsel (University College London, London, UK); rabbit anti-green fluorescent protein (GFP) was provided by Dr. David Shima (Imperial Cancer Research Fund, London, UK); anti-CD63, 1B5 was prepared in house (see below); anti-Lgp120, rabbit antibody against human LAMP1 was provided by Dr. Sven Carlsson (University of Umeå, Umeå, Sweden); anti-transferrin receptor H68.4 was purchased from Zymed Laboratories (San Francisco, CA); rabbit antibody against the $\gamma$ subunit of AP-1 was provided by Dr. Margaret Robinson (University of Cambridge, Cambridge, UK); anti-vesicular stomatitis virus G-protein, P5D4 was provided by Dr. Thomas. Kreis (University of Geneva, Geneva, Switzerland); anti-HCMV-IE1, MAB810 (Chemicon, Temecula, CA); rabbit anti-mouse labeled with Alexa Flour-594 (Molecular Probes, Eugene, OR). Horseradish peroxidase (HRP)-conjugated and other fluorescent second antibody reagents were from Pierce \& Warriner (Chester, UK).

Q4120 and MC-5 were ${ }^{125}$ I-labeled with the use of Bolton and Hunter reagent (Amersham Pharmacia Biotech) as described (Signoret et al., 1997). Specific activities of 400-500 Ci/mmol were obtained for different iodinations. Radioiodinated proteins, diluted in phosphate-buffered saline (PBS) containing $0.25 \%$ gelatin and $0.02 \% \mathrm{NaN}_{3}$ and stored in small aliquots at $-20^{\circ} \mathrm{C}$, were stable for at least 4 months.

Generation of the Monoclonal Anti-CD63 Antibody Mice were immunized with a heavy membrane fraction from the human epidermoid cell line Hep2. Spleen cells were fused with NS-1 myeloma cells and the fusions were plated into 96-well plates. Wells containing viable hybridomas were screened by immunofluorescence on Hep2 cells. 1B5 was one of several wells that gave strong punctate fluorescence on permeabilized cells. A hybridoma line was cloned by limiting dilution and the cognate antigen identified by Western blotting and cDNA expression as follows: Western blotting of Hep2 cell lysates indicated a broad band of mean molecular mass of approximately $60 \mathrm{kDa}$, similar to bands recognized by commercial anti-CD63 antibodies (Bowers and Marsh, unpublished results). Expression of the cDNA for human CD63 (kindly provided by Dr. Paul Luzio, University of Cambridge, Cambridge, UK) in Chinese hamster ovary $(\mathrm{CHO})$ cells confirmed that $1 \mathrm{~B} 5$ recognizes human CD63 (Bowers and Marsh, unpublished results). Subsequent studies indicated that this monoclonal antibody is specific to simian and 
human CD63 and recognizes an epitope in the ecto (luminal) domain of this tetraspanin.

\section{Cells}

HeLa cells were maintained in DMEM containing $4 \%$ fetal calf serum (FCS), $2 \mathrm{mM}$ glutamine, $100 \mathrm{U} / \mathrm{ml}$ penicillin, and $0.1 \mathrm{mg} / \mathrm{ml}$ streptomycin (PenStrep). Cos-7 cells were maintained in DMEM containing $10 \%$ FCS, glutamine, and PenStrep as above. Mink Mv1-Lu cells stably expressing the CD4-chemokine receptor hybrid CD4(2D)CXCR4, consisting of the $2 \mathrm{~N}$-terminal Ig domains of CD4 linked directly to the $\mathrm{N}$ terminus of human CXCR4 (Klasse et al., 1999) and CHO cells stably expressing human CCR5 (Mack et al., 1998), were maintained in DMEM containing $10 \%$ FCS, glutamine, PenStrep, and $1 \mathrm{mg} / \mathrm{ml} \mathrm{G418}$ as above. HeLa and Cos-7 cells were transfected by electroporation (Bio-Rad, Hemel Hempstead, UK). HeLa CD4-US28 stable transfectants were selected in medium containing $1 \mathrm{mg} / \mathrm{ml} \mathrm{G418,} \mathrm{and} \mathrm{colonies} \mathrm{were} \mathrm{screened} \mathrm{for} \mathrm{CD4-US28}$ expression by immunofluorescence with the use of Q4120. HeLa CD4-US28 cells were maintained in DMEM containing 4\% FCS, glutamine, PenStrep, and G418 as above. Human foreskin fibroblasts were grown in DMEM containing 10\% NU-serum I culture supplement (Becton Dickinson, Bedford, MA), $100 \mathrm{U} / \mathrm{ml}$ penicillin, and $100 \mathrm{mg} / \mathrm{ml}$ streptomycin.

\section{Western Blotting}

HeLa cells expressing US28 constructs were lysed in RIPA buffer (20 $\mathrm{mM}$ Tris- $\mathrm{HCl}, \mathrm{pH} 7.8,150 \mathrm{mM} \mathrm{NaCl}$ supplemented with $1 \%$ Nonidet $\mathrm{P}-40,1 \%$ sodium deoxycholate, $0.1 \%$ SDS, 2 mM EDTA) containing the protease inhibitors phenylmethylsulfonyl fluoride (at 1 $\mathrm{mM})$ and CLAP $(5 \mu \mathrm{g} / \mathrm{ml}$ each of chymostatin, pepstatin A, antipain hydrochloride, and $10 \mu \mathrm{g} / \mathrm{ml}$ leupeptin hemisulfate). After removal of the nuclei and cell debris by centrifugation at $13,000 \times g$ for $10 \mathrm{~min}$ at $4^{\circ} \mathrm{C}$ the lysates were loaded on $10 \%$ SDS-polyacrylamide gels under nonreducing conditions without heating. After electrophoresis, proteins were transferred to nitrocellulose membranes (Schleicher \& Schuell, Dassel, Germany). The blots were incubated in blocking buffer $(10 \%$ skimmed milk powder, $0.1 \%$ Tween-20 in PBS) for $1 \mathrm{~h}$ at room temperature. Incubations with primary and secondary antibodies were in blocking buffer for $1 \mathrm{~h}$ each at room temperature. To detect CD4-US28, Q4120 $(2.5 \mu \mathrm{g} / \mathrm{ml})$ and HRP-conjugated goat anti-mouse antibodies were used. The rabbit antibody against GFP and HRP-conjugated goat anti-rabbit antibody (both at 1:2000) were used to detect US28-GFP. Blots were developed with the use of enhanced chemiluminescence (Amersham Pharmacia Biotech) and visualized with autoradiography film (Fuji Photo Film, Tokyo, Japan)

\section{Immunofluorescence Microscopy}

HeLa cells stably expressing CD4-US28, and HeLa or Cos cells transiently transfected with US28 constructs, were grown on glass coverslips and used $2 \mathrm{~d}$ after electroporation. Unless indicated otherwise, cells were first fixed with $3 \%$ paraformaldehyde in PBS for $10 \mathrm{~min}$ at room temperature, quenched with $\mathrm{NH}_{4} \mathrm{Cl}$, and then stained with appropriate antibodies with or without permeabilization with $0.05 \%$ saponin, essentially as described (Signoret et al., 1997). After staining, cells were mounted in Moviol and analyzed with the use of an Optiphot-2 microscope (Nikon, Tokyo, Japan) equipped with an MRC Bio-Rad 1024 confocal laser scanning system. Digital images were transferred to Adobe Photoshop (Adobe Systems, Mountain View, CA) and adjusted so that all intensity values were in the measurable range (0-255 gray levels). Single channel and overlay images were printed directly from Adobe Photoshop.

\section{Immunolabeling of Cryosections for Electron Microscopy}

HeLa cells transiently transfected with US28-GFP were grown in 90-mm tissue culture dishes. After $2 \mathrm{~d} 30-40 \%$ of the cells expressed the GFP-tagged proteins, although $<10 \%$ of the cells showed high expression levels. The cells were fixed by adding an equal volume of prewarmed double-strength fixative ( $8 \%$ paraformaldehyde, $0.1 \%$ glutaraldehyde in $0.1 \mathrm{M}$ sodium phosphate buffer, $\mathrm{pH}$ 7.4) directly into the culture medium. After $10 \mathrm{~min}$, the medium was replaced with single-strength fixative ( $4 \%$ paraformaldehyde, $0.05 \%$ glutaraldehyde). Fixed cells were washed in PBS containing $20 \mathrm{mM}$ glycine and embedded in 10\% gelatin (ICN Pharmaceuticals, Costa Mesa, CA), infiltrated with 2.3 M sucrose, and frozen in liquid nitrogen as described (Raposo et al., 1997). Cryosections $(\sim 60 \mathrm{~nm}$ thick) were labeled with a rabbit antibody against GFP, and bound antibodies were detected with protein A-gold (EM Lab, Utrecht University, The Netherlands). Sections were examined with an EM420 transmission electron microscope (Phillips, Eindhoven, The Netherlands).

\section{HCMV Infections}

Human foreskin fibroblasts grown in chamber slides were transfected with US28-YFP with the use of Superfect (Qiagen, Valencia, CA) and immediately after transfection were infected with the Towne strain of HCMV at a multiplicity of infection of infection unit/cell. At the chosen time points after infection, cells were fixed in $3.7 \%$ paraformaldehyde in PBS at room temperature and stained with anti-IE1 antibody $(1: 1000)$ after permeabilization in $0.2 \%$ Triton X-100 for $20 \mathrm{~min}$ on ice. Secondary rabbit anti-mouse antibody labeled with Alexa Flour-594 as used at 1:1000. Cell nuclei were stained with $1 \mu \mathrm{g} / \mathrm{ml}$ Hoechst (Molecular Probes) in PBS. After staining, cells were mounted in FluoroGuard antifade reagent (BioRad, Hercules, CA) and analyzed with the use of an Applied Precision DeltaVision Deconvolution system (Applied Precision, Issaquah, WA) connected to an IX-70 inverted microscope (Olympus, New Hyde Park, NY) with a mercury arc bulb as the illumination source. After image acquisition, the raw data were deconvoluted using the modifications made to the inverse matrix algorithm by Agard and Sedat (1983).

\section{Antibody-feeding and Antibody-recycling Experiments}

For antibody-feeding experiments HeLa CD4-US28-expressing cells were grown on coverslips for $48 \mathrm{~h}$. The cells were washed in binding medium (BM: RPMI-1640 without bicarbonate, containing $0.2 \%$ bovine serum albumin, $10 \mathrm{mM}$ HEPES, and adjusted to $\mathrm{pH} 7.4$ ) at room temperature. Subsequently, the cells were incubated in BM containing anti-CD4 Q4120 ( $\sim 60 \mathrm{nM})$ at $37^{\circ} \mathrm{C}$. After $1 \mathrm{~h}$ the coverslips were placed on ice and washed with cold BM. To remove cell surface-bound antibody, the cells were washed twice in BM adjusted to $\mathrm{pH} 3.0$, followed by two 3-min incubations in the same medium, and returned to $\mathrm{BM}, \mathrm{pH}$ 7.4. The cells were then fixed in PBS containing 3\% paraformaldehyde for $10 \mathrm{~min}$, stained with rhodamine-conjugated goat anti-mouse antibody (Pierce \& Warriner), with or without permeabilization with $0.05 \%$ saponin, and examined by confocal microscopy.

For antibody-recycling experiments HeLa CD4-US28 cells on glass coverslips were incubated in BM with anti-CD4 Q4120 antibody for $1 \mathrm{~h}$, acid washed as above, and returned to $\mathrm{pH}$ 7.4. The cells were then reincubated in BM with a biotin-conjugated antimouse antibody (Amersham Pharmacia Biotech) at $37^{\circ} \mathrm{C}$. After $1 \mathrm{~h}$ the coverslips were placed on ice, washed with cold BM, acid washed, and fixed in PBS containing 3\% paraformaldehyde. Cells, either intact or permeabilized with $0.05 \%$ saponin, were stained with fluorescein-conjugated streptavidin (Amersham Pharmacia 
Biotech) for $45 \mathrm{~min}$. Subsequently the coverslips were mounted in Moviol and examined as above.

\section{Endocytosis Assays}

Endocytosis assays on adherent cells were performed essentially as described (Pelchen-Matthews et al., 1991). Briefly, cells were seeded in 16-mm wells in 24-well plates and grown for $2 \mathrm{~d}$ to a final density of $\sim 2.5 \times 10^{5}$ cells per well. The cells were cooled on ice, washed with DMEM containing $4 \% \mathrm{FCS}$, and incubated for $2 \mathrm{~h}$ at $4{ }^{\circ} \mathrm{C}$ with $250 \mu \mathrm{l}$ of either $0.5 \mathrm{nM}^{125} \mathrm{I}-\mathrm{Q} 4120$ antibody or $125 \mathrm{pM}^{125} \mathrm{I}$-RANTES in DMEM. Subsequently, the cells were washed in DMEM to remove free ligand and then warmed by addition of $1 \mathrm{ml}$ DMEM at $37^{\circ} \mathrm{C}$. At the indicated times the cells were returned to $4^{\circ} \mathrm{C}$ and washed with cold DMEM. For each time point at least four wells were used. For half of the wells, the cells were collected directly in $400 \mu \mathrm{l}$ of $0.2 \mathrm{M} \mathrm{NaOH}$ and transferred to tubes for $\gamma$ counting (total cell-associated activity). To determine the intracellular activity, the remaining wells were acid washed to remove cell surface ligand (acid-resistant activity). The cells were harvested in $\mathrm{NaOH}$ as above. The proportion of internalized activity for each time point was determined by dividing the acid-resistant activity by the total cellassociated activity and endocytic rates were calculated by analysis of the data from the first 5 min of warming.

\section{Down-Modulation Assays}

Cells plated in 16-mm wells of a 4-well plate were incubated in DMEM or in DMEM containing Q4120, RANTES, or fractalkine at $37^{\circ} \mathrm{C}$ as indicated in the text. After treatment, the cells were placed on ice and cooled by addition of $1 \mathrm{ml}$ of ice-cold DMEM and four washes with the same medium. The cells treated with Q4120 were acid washed to remove the cell surface-bound antibody. The cells were returned to $\mathrm{pH} 7.4$ by washes in cold DMEM and then labeled with $250 \mu \mathrm{l}$ of $0.5 \mathrm{nM}{ }^{125} \mathrm{I}-\mathrm{Q} 4120$ for $2 \mathrm{~h}$ at $4^{\circ} \mathrm{C}$ under agitation. Subsequently, the cells were washed again in cold DMEM, and harvested in $400 \mu \mathrm{l}$ of $0.2 \mathrm{M} \mathrm{NaOH}$, and the bound radioactivity was measured as above.

\section{RESULTS}

\section{Subcellular Localization of US28}

The chemokine receptor-like putative 7TM proteins encoded by HCMV and related viruses have important, yet poorly understood, roles in viral tropism and pathogenesis. Little is known of where these proteins are located in infected cells or how this distribution is achieved and related to the function of the proteins because few antibodies are available to HCMV 7TM proteins. We used tagged constructs to examine the distribution of the HCMV chemokine receptor US28. GFP was fused to the C-terminal cytoplasmic domain of US28, or epitope tags containing the $2 \mathrm{~N}$-terminal Ig-domains of human CD4 (Klasse et al., 1999) or a nine-amino acid epitope of influenza HA were fused to the extracellular $\mathrm{N}$-terminal domain (Figure 1A). We analyzed the expression of US28-GFP and CD4-US28 in HeLa and Cos cells by Western blot and immunoprecipitation (Figure 1B). Both constructs showed a single band. Under the nonreducing conditions required for CD4 blotting, the electrophoretic mobilities may not precisely reflect the molecular masses. Nevertheless, CD4-US28 and US28-GFP showed a relative mobility corresponding to $\sim 60 \mathrm{kDa}$. US28-GFP occasionally yielded a higher band at $\sim 120 \mathrm{kDa}$ that may be due to receptor dimerization. Immunoprecipitation of CD4-US28 from ${ }^{35}$ S-Met-labeled cells produced a band of similar rela-
A
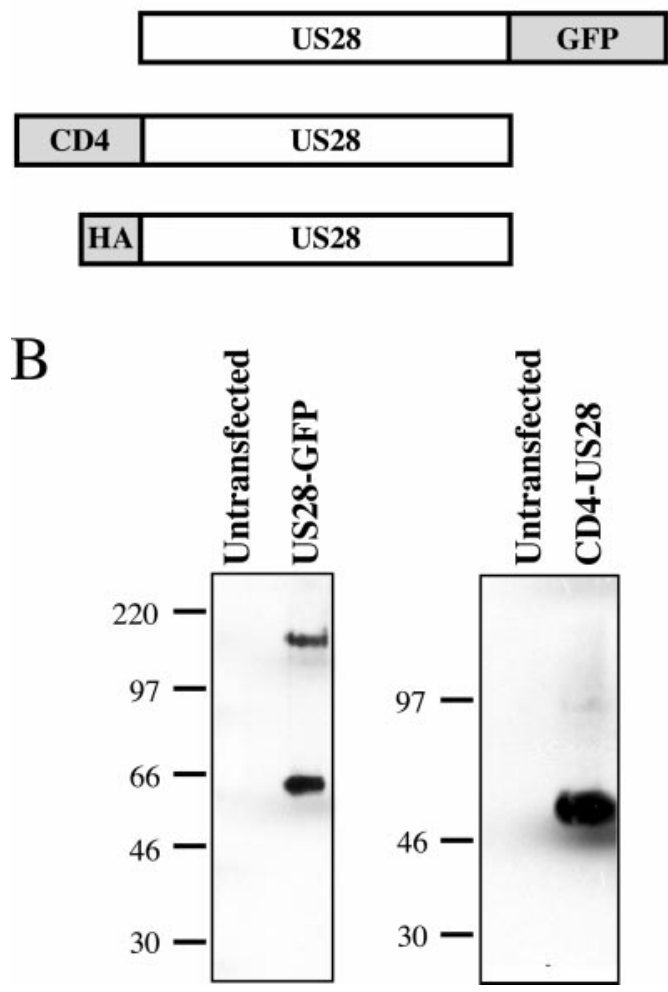

Figure 1. Schematic representation and Western blot of US28 constructs. (A) GFP was linked to the C terminus of US28 (US28-GFP). The two N-terminal Ig domains of CD4 or a nine-amino acid epitope from the influenza virus HA were fused to the N-terminal ectodomain of US28 (CD4-US28 and HA-US28). (B) Western blots of lysates of HeLa cells transiently transfected with US28-GFP or CD4US28. The CD4 moiety was detected with Q4120 and GFP with a rabbit antibody against GFP. Molecular weight standards (the masses are given in $\mathrm{kDa}$ ) migrated as indicated on the left. The mass of the US28 moiety predicted from the amino acid sequence is $\sim 41$ $\mathrm{kDa}$; two domains of CD4 or the GFP moiety have predicted masses of 22 and $26 \mathrm{kDa}$, respectively.

tive mobility (Fraile-Ramos and Marsh, unpublished results).

Initial analysis of constructs expressed in Hela or COS cells indicated that the majority of US28-GFP was located intracellularly in punctate structures frequently concentrated on one side of the nucleus (Figure 2A). Little fluorescence was seen at the cell surface. To exclude the possibility that GFP tagging caused mislocalization of US28, the chemokine receptor CXCR4 was similarly tagged (CXCR4-GFP) and expressed in Hela cells and found to be distributed primarily at the cell surface (Fraile-Ramos, Kledal, Schwartz, and Marsh, unpublished results), as previously described (Signoret et al., 1997). In addition, we expressed CD4-US28 and HA-US28. After staining with anti-CD4 or anti-HA antibodies, prominent intracellular staining was observed with both constructs (Figure 2C). Coexpression of CD4-US28 with US28-GFP indicated that both proteins were mostly located within the same cytoplasmic structures. Staining of CD4- 

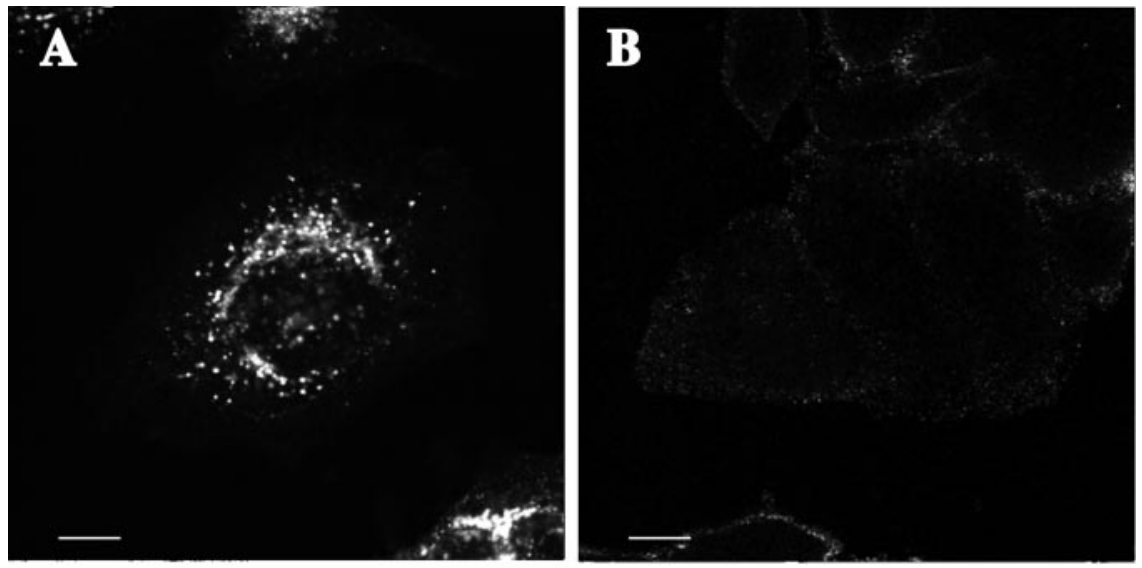

Figure 2. Subcellular localization and quantification of US28. Localization of US28-GFP in transiently transfected HeLa cells (A). HeLa cells expressing CD4-US28 were stained with an antibody against CD4 either without (B) or after permeabilization with saponin (C). Scale bars $=10 \mu \mathrm{m}$. (D) ${ }^{125} \mathrm{I}-\mathrm{Q} 4120$ was used to quantify CD4-US28 distribution. Intact HeLa CD4-US28 cells were incubated with ${ }^{125} \mathrm{I}-\mathrm{Q} 4120$ to determine the protein at the cell surface, and cells permeabilized with saponin were used to determine the total protein present in the cell. HeLa cells, intact or permeabilized with saponin, were incubated with ${ }^{125} \mathrm{I}-\mathrm{Q} 4120$ to determine the unspecific binding. The plots show the bound radioactivity as counts per minute per well after subtraction of the nonspecific binding.
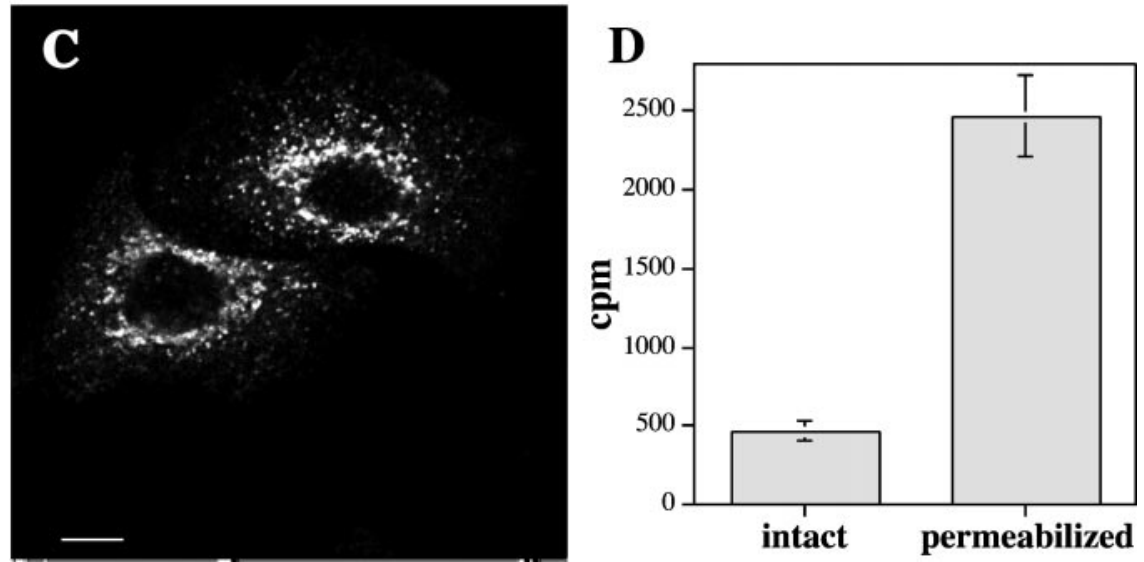

US28-expressing cells without permeabilization indicated a low level of the transfected construct on the cell surface (Figure 2B). CD4-US28 showed a similar staining pattern, both after transient transfection and in stably transfected cell lines. Biochemical analysis of Hela CD4-US28 cells with ${ }^{125}$ I-labeled anti-CD4 antibodies, with or without permeabilization with saponin, indicated that at most $20 \%$ of the CD4-US28 construct was present at the cell surface (Figure 2D).

We next investigated where US28 was located by doublelabel immunofluorescence. US28-GFP-expressing cells were stained with antibodies against the transferrin receptor, or against Lgp120 and CD63, markers for recycling endosomes and late endosomes/lysosomes, respectively. In addition, an antibody against the $\gamma$ subunit of the AP- 1 adaptor complex was used as a marker for the trans-Golgi network, although this antibody may also label components of early endosomes (Futter et al., 1998). Significant overlap of US28 with markers for recycling endosomes (Fraile-Ramos and Marsh, unpublished results) and late endosomes/lysosomes was seen, although in all cases US28-containing vesicles that lacked these markers were also observed (Figure 3). Little overlap of US28 with $\gamma$-adaptin was seen (Fraile-Ramos and Marsh, unpublished results).

Very similar distributions were seen with US28 proteins carrying markedly different tags, arguing that the distribution is due to intrinsic properties of US28 and is not influenced by tag addition. Together, these results indicate that the HCMV chemokine receptor US28 was mostly distributed in intracellular organelles, although a minor proportion was seen at the cell surface. Moreover, intracellular US28 showed overlap with markers for the endocytic pathway including early and late endosomes.

\section{Electron Microscopy (EM) Immunolocalization of US28}

To identify the distribution of US28 at higher resolution, we studied the GFP chimera by EM of immunolabeled cryosections. HeLa cells transiently transfected with US28-GFP were grown for $2 \mathrm{~d}$ before fixation and embedding for immuno-EM. Cryosections were cut and labeled with a rabbit anti-GFP antibody and protein-A gold. Specific labeling for US28-GFP was found to be associated with multivesicular endosomal structures located in the juxtanuclear region of the cell (Figure 4, A and B). Gold particles were found over both the limiting membrane of the multivesicular endosomes and over the internal vesicles. This labeling is very similar to the distribution of the late endosome/lysosome marker CD63, which also labels multivesicular bodies (Figure 4C). Lower levels of US28-GFP were also found at other sites. Gold particles could be observed at the cytoplasmic face of the plasma membrane of US28-GFP-expressing cells. Occasionally, cell surface gold particles could be seen associated with coated pits (Figure 4A), suggesting that the protein may be internalized by the clathrin-mediated path- 

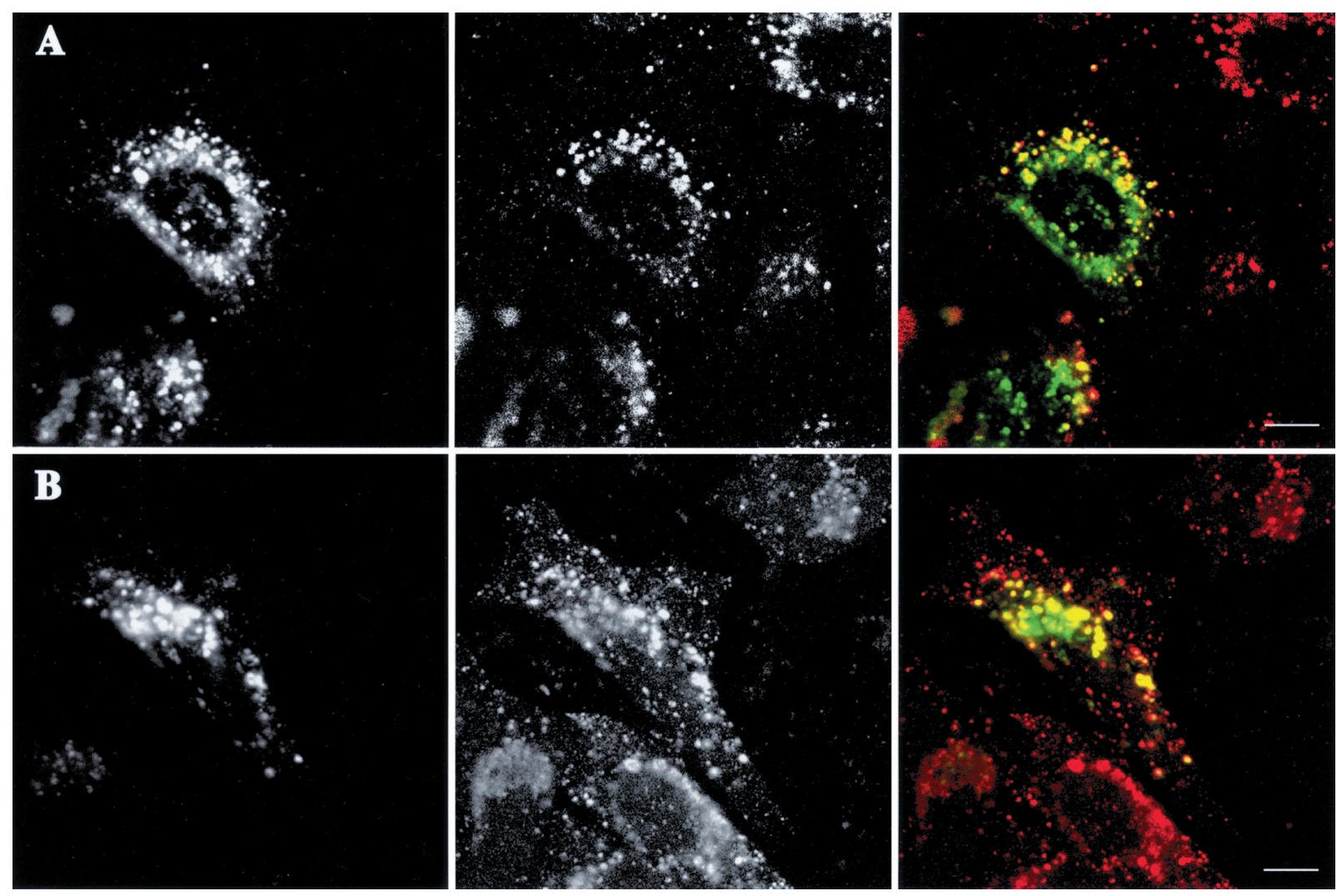

Figure 3. Colocalization of US28 with markers for late endosomes and lysosomes. HeLa cells transfected with US28-GFP (left-hand panels and in green) were stained with an antibody against CD63 and LAMP-1 (A and B, respectively, middle panels and in red), markers for late endosomes and lysosomes. Vesicles positive for both markers are seen in yellow on the right, merged panels. Scale bars, $10 \mu \mathrm{m}$.

way. In addition, there was some labeling of small tubules and vesicles, which may correspond to early endosomes.

\section{US28 Undergoes Endocytosis}

Although most US28 is found intracellularly, some of the protein is seen at the cell surface as indicated above and by previous pharmacological studies (Neote et al., 1993; Gao and Murphy, 1994; Kledal et al., 1998). To investigate whether cell surface US28 undergoes endocytosis we carried out antibody-feeding experiments. HeLa cells stably expressing CD4-US28 were incubated in medium containing an antibody against CD4, Q4120, at $37^{\circ} \mathrm{C}$. Cell surface antibody was removed by acid washing, and antibody uptake was assessed by immunofluorescence staining of permeabilized cells with a fluorescent anti-mouse antibody. After 60 min at $37^{\circ} \mathrm{C}$ a clear pattern of intracellular vesicular staining was seen (Figure 5A). Staining of cells without permeabilization showed no fluorescence, indicating that little or no antibody remained at the cell surface after the acid wash (Figure 5B). To ensure that the labeling was dependent on CD4-US28-mediated uptake of the antibody, internalization of an irrelevant antibody (anti-VSV-G) was assessed on CD4-US28-expressing cells. In addition, the anti-CD4 and anti-VSV-G antibodies were added to untransfected HeLa cells. No staining of these controls was seen (Fraile-Ramos and Marsh, unpublished results). These results support the hypothesis that cell surface US28 can undergo endocytosis.

To measure CD4-US28 endocytosis directly we used ${ }^{125} \mathrm{I}-$ Q4120. HeLa CD4-US28 cells were labeled with ${ }^{125} \mathrm{I}-\mathrm{Q} 4120$ for $2 \mathrm{~h}$ at $4^{\circ} \mathrm{C}$, washed, and then warmed to $37^{\circ} \mathrm{C}$ for various times to allow endocytosis. Antibody remaining at the cell surface was removed by acid wash, and the remaining acidresistant activity was determined. Control experiments indicated that $>95 \%$ of the antibody bound to the cell surface at $4^{\circ} \mathrm{C}$ was eluted under these conditions.

As indicated in Figure 6A bound ${ }^{125} \mathrm{I}-\mathrm{Q} 4120$ was internalized rapidly ( $\sim 7 \%$ of the cell surface pool $/ \mathrm{min}$, measured over the first $5 \mathrm{~min}$ of warm up). After $60 \mathrm{~min}$ at $37^{\circ} \mathrm{C} \sim 90 \%$ of the initial cell-associated radioactivity was intracellular. To compare this uptake to the endocytosis of a related 7TM GPCR, internalization of CXCR4 on Mink Mv-1-Lu cells expressing an equivalent CD4-CXCR4 hybrid (CD4(2D)CXCR4) was measured (Klasse et al., 1999). The rapid constitutive US28 endocytosis was faster than the phorbol ester-induced endocytosis of CD4-CXCR4 and was similar to ligand-induced endocytosis of CD4-CXCR4 (Figure 6B), suggesting that the endocytic properties of US28 are similar to those of a ligandactivated receptor.

It has been established that agonist binding can initiate signaling responses and rapid internalization of cell surface chemokine receptors (Pelchen-Matthews et al., 1999). US28 

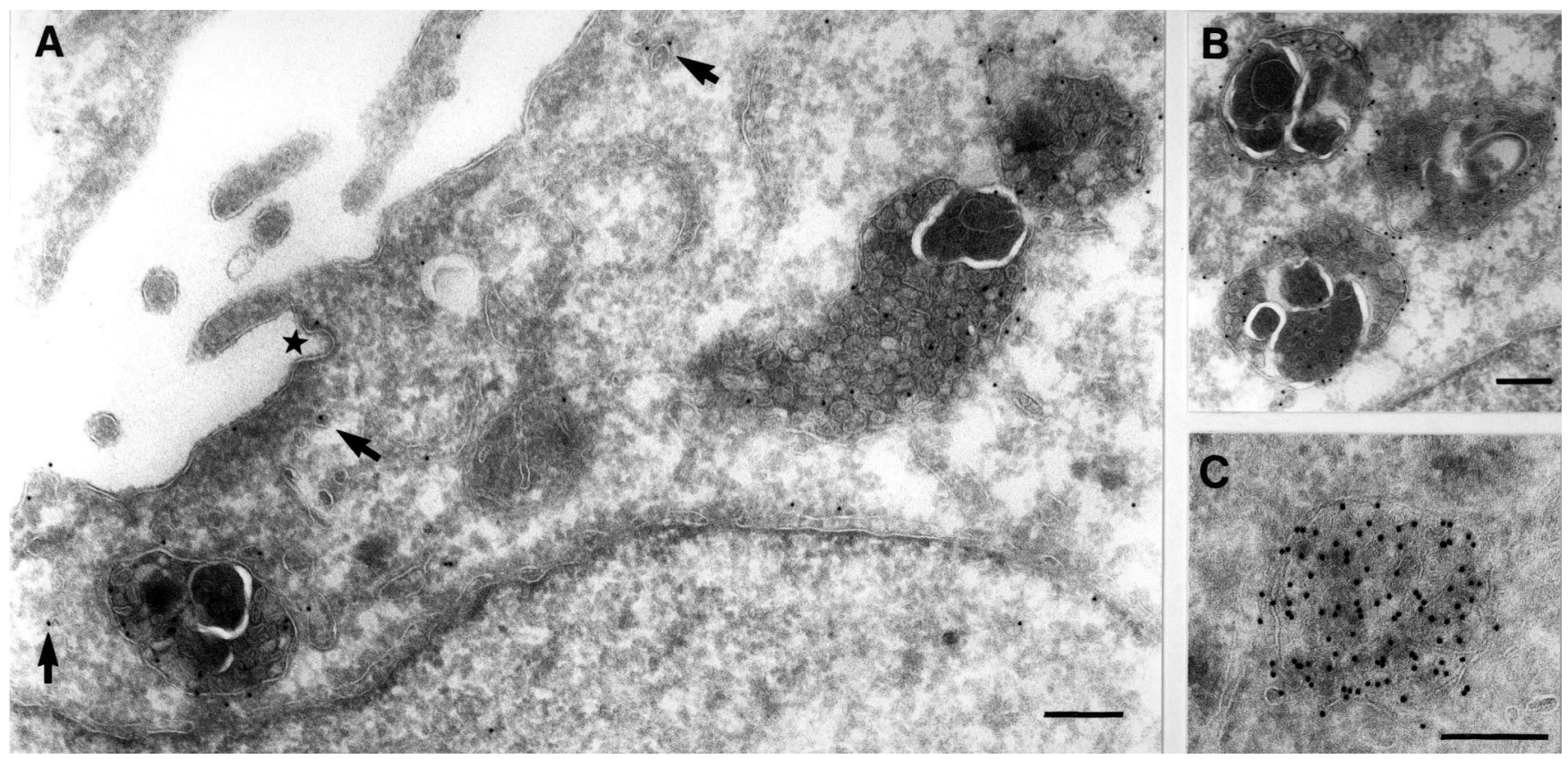

Figure 4. EM immunolocalization of US28. (A and B) Cryosections of HeLa cells transiently expressing US28-GFP were stained with an anti-GFP antibody and 10-nm protein A-gold particles $\left(\mathrm{PAG}_{10}\right)$. Most of the gold particles were found associated with multivesicular endosomes, both over the limiting membrane and over internal vesicles. Some gold particles were also found at the plasma membrane (including coated pits, asterisk in A) and in small tubular structures and vesicles that could correspond to endosomes (arrows in A). (C) Cryosections of HeLa cells stained with the anti-CD63 antibody 1B5 and PAG 10 also showed enriched labeling of multivesicular bodies. Scale bars, $200 \mathrm{~nm}$.

binds several CC-chemokines and fractalkine with high affinity (Neote et al., 1993; Gao and Murphy, 1994; Kledal et al., 1998). To determine whether the CC-chemokine RANTES induced endocytosis of US28, we used ${ }^{125}$ I-RANTES (Signoret et al., 2000). HeLa CD4-US28 cells were labeled with 125
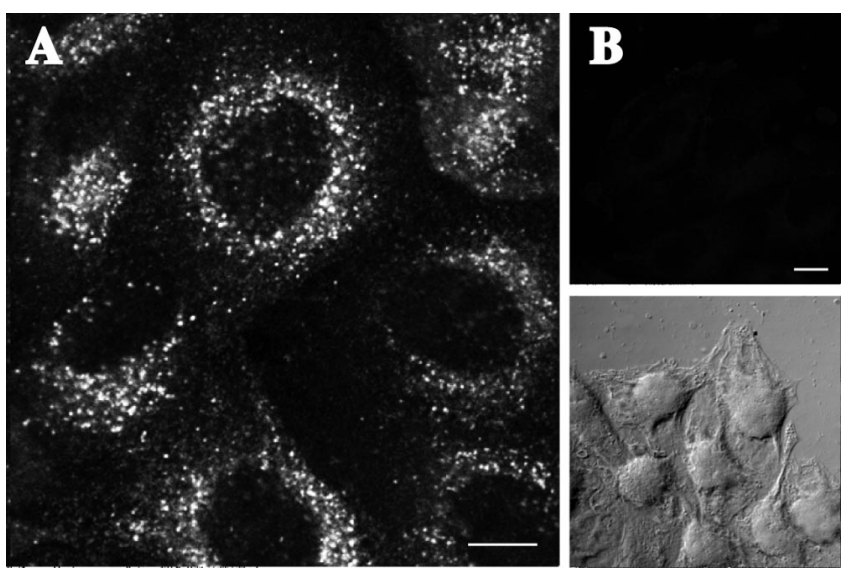

Figure 5. Internalization of US28. HeLa cells stably expressing CD4-US28 were incubated with an antibody against CD4, Q4120, at $37^{\circ} \mathrm{C}$ for $1 \mathrm{~h}$ to allow internalization. After acid washing to remove the antibody bound to the cell surface the cells were fixed. Cells permeabilized with saponin (A) or intact (B, top and bottom show the same field) were stained with a rhodamine-conjugated secondary antibody to detect Q4120. Scale bars, $10 \mu \mathrm{m}$.
pM ${ }^{125}$ I-RANTES (a concentration at which RANTES shows little binding to cell surface glycosaminoglycans) for $2 \mathrm{~h}$ at $4^{\circ} \mathrm{C}$, washed, and then warmed to $37^{\circ} \mathrm{C}$. The amount of internalized ligand was determined by acid washing the cells with media adjusted to $\mathrm{pH} 2.0$, which eluted $>90 \%$ of
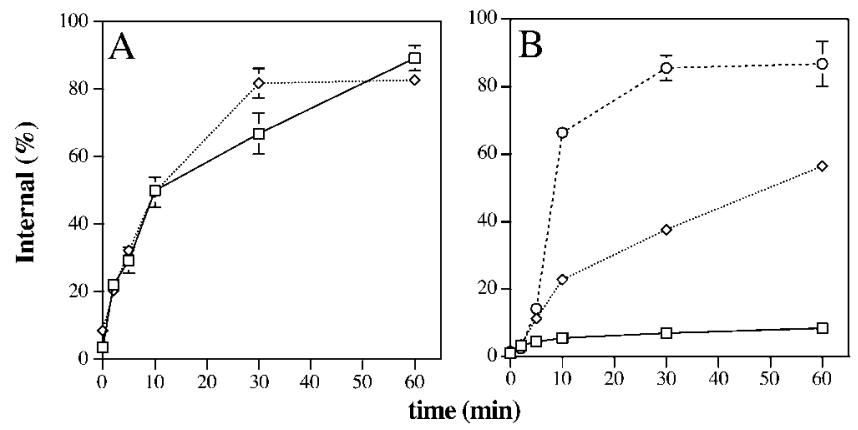

Figure 6. Endocytosis of US28. (A) HeLa CD4-US28 cells were labeled at $4^{\circ} \mathrm{C}$ with ${ }^{125} \mathrm{I}$-Q4120 $(\square)$ or ${ }^{125} \mathrm{I}$-RANTES $(\diamond)$, washed, and warmed to $37^{\circ} \mathrm{C}$ to allow endocytosis. The amount of internalized ligand was determined by acid washing as described in MATERIALS AND METHODS. (B) Mv-1-Lu cells expressing the hybrid CD4(2D)CXCR4 were labeled at $4^{\circ} \mathrm{C}$ with ${ }^{125} \mathrm{I}-\mathrm{Q} 4120 \mathrm{for} 2 \mathrm{~h}$ and then warmed to $37^{\circ} \mathrm{C}$ in $\mathrm{BM}(\square)$, BM containing $100 \mathrm{ng} / \mathrm{ml}$ phorbol myristate acetate $(\diamond)$, or $250 \mathrm{nM}$ SDF-1 $(\bigcirc)$. At the indicated times the cells were cooled and the internalized antibody was determined. The plots show the acid-resistant radioactivity (internal) as a proportion of the total cell-associated activity. All data points show means and SDs for duplicate samples from a representative experiment. 

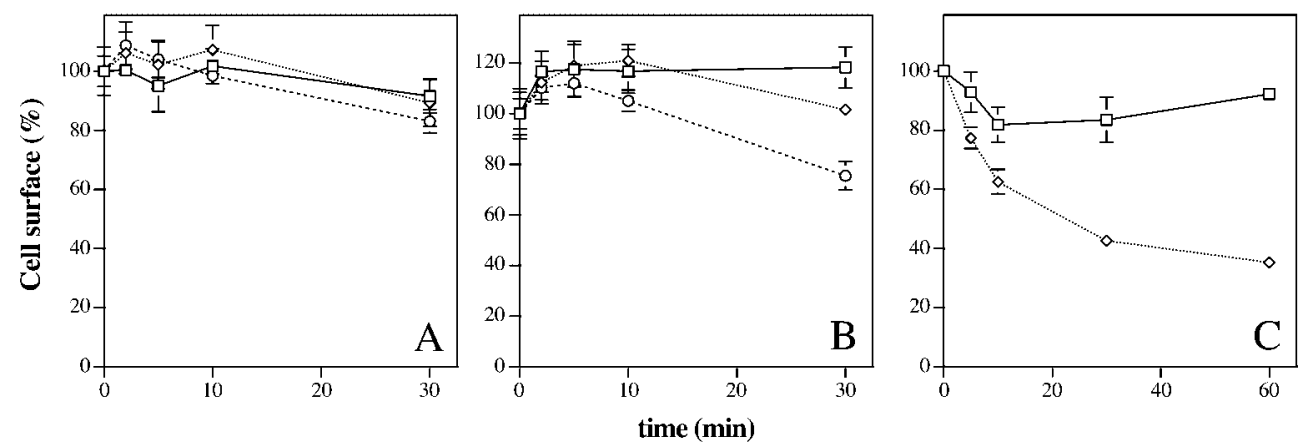

Figure 7. Down-modulation of US28 and CCR5. (A) HeLa CD4US28 cells were incubated in medium $(\square)$, or in medium containing $0.3 \mathrm{nM}(\diamond)$, or $2.5 \mathrm{nM}(\bigcirc)$ unlabeled Q4120 antibody at $37^{\circ} \mathrm{C}$ for the indicated times. The cells were acid washed and the cell surface CD4-US28 molecules were then detected by labeling with ${ }^{125} \mathrm{I}-\mathrm{Q} 4120$ antibody for $2 \mathrm{~h}$ at $4^{\circ} \mathrm{C}$. (B) HeLa CD4-US28 cells were incubated in medium ( $\square$ ), medium containing $100 \mathrm{nM}$

RANTES $(\diamond)$, or $100 \mathrm{nM}$ fractalkine $(\bigcirc)$ for up to $30 \mathrm{~min}$ at $37^{\circ} \mathrm{C}$. At the indicated times the cells were cooled on ice, washed with cold medium, and labeled as in A with ${ }^{125} \mathrm{I}-\mathrm{Q} 4120$ to detect cell surface CD4-US28. (C) CHO-CCR5 cells were incubated in medium ( $\square$ ) or medium containing $100 \mathrm{nM}$ RANTES $(\diamond)$ for the indicated times at $37^{\circ} \mathrm{C}$. The cells were cooled on ice, washed with cold medium, and then labeled with ${ }^{125} \mathrm{I}-\mathrm{MC}-5$ at $4^{\circ} \mathrm{C}$ to determine the cell surface levels of CCR5. Each point shows the mean and SD of triplicate samples from a representative experiment.

the cell surface ${ }^{125}$ I-RANTES. In HeLa CD4-US28 cells, ${ }^{125} \mathrm{I}-$ RANTES underwent a rapid endocytosis $(\sim 6 \%$ of the cell surface $\mathrm{pool} / \mathrm{min}$ ) that reached steady state between 30 and $60 \mathrm{~min}$, when $\sim 80 \%$ of the initial cell surface pool was inside the cells. The kinetics of US28 endocytosis measured with ${ }^{125} \mathrm{I}-\mathrm{RANTES}$ were very similar to those observed for ${ }^{125} \mathrm{I}-$ Q4120 (Figure 6A).

The observation that both ${ }^{125} \mathrm{I}-\mathrm{Q} 4120$ and ${ }^{125} \mathrm{I}-\mathrm{RANTES}$ were internalized at similar rates suggests that US28 may undergo endocytosis constitutively. To exclude the possibility that the rapid endocytosis of US28 was induced by antibody binding or by the ligand, HeLa CD4-US28 cells were incubated with unlabeled Q4120 or RANTES for up to $30 \mathrm{~min}$ at $37^{\circ} \mathrm{C}$; at the indicated times the cells were transferred to ice. For cells treated with unlabeled Q4120, antibody remaining at the cell surface was removed by incubating the cells in cold media adjusted to $\mathrm{pH}$ 3.0. The cells were then labeled with ${ }^{125} \mathrm{I}-\mathrm{Q} 4120$ for $2 \mathrm{~h}$ at $4^{\circ} \mathrm{C}$ to determine the level of CD4-US28 remaining at the cell surface. Figure 7A shows that incubation with 0.3 or $2.5 \mathrm{nM}$ Q4120 at $37^{\circ} \mathrm{C}$ did not induce down-modulation of cell surface US28. Similarly, 100 nM RANTES induced very little down-modulation of US28 (Figure 7B). To ensure that ligand and antibody did not compete for binding to US28, HeLa CD4-US28 cells were incubated with $0.5 \mathrm{nM}{ }^{125} \mathrm{I}-\mathrm{Q} 4120$ in the presence or absence of $100 \mathrm{nM}$ RANTES and with $125 \mathrm{pM}{ }^{125}$ I-RANTES in the presence or absence of $2.5 \mathrm{nM}$ Q4120. Similar levels of Q4120 and RANTES binding, respectively, were observed on both treated and untreated cells (Fraile-Ramos and Marsh, unpublished results). The preparation of RANTES used for these experiments was tested for its ability to down-modulate the human chemokine receptor CCR5. RANTES induced a rapid down-modulation of cell surface CCR5 expressed in CHO cells (Figure 7C).

Together these results indicate that the HCMV chemokine receptor US28 is rapidly endocytosed. This endocytosis is not induced by the presence of the ligand RANTES or by antibody binding, but represents constitutive endocytosis. The kinetics of endocytosis of US28 are similar to those of an activated chemokine receptor. In addition, the failure of RANTES or Q4120 to down-modulate cell surface US28 levels suggests that internalized receptors are recycled to the cell surface.

\section{US28 Recycles to the Plasma Membrane}

To observe recycling of internalized US28 we carried out an antibody-feeding experiment in the presence of cycloheximide. HeLa CD4-US28 cells were treated with cycloheximide for up to $2 \mathrm{~h}$ to stop the synthesis of new proteins and then incubated with medium containing cycloheximide and ${ }^{125} \mathrm{I}-\mathrm{Q} 4120$ for $1 \mathrm{~h}$ at $37^{\circ} \mathrm{C}$ to determine the levels of antibody uptake. Antibody remaining at the cell surface was removed by washing the cells in cold media adjusted to $\mathrm{pH}$ 2.0. A second set of cells was treated similarly but without cycloheximide. Treatment with cycloheximide had no significant effect on antibody uptake (Fraile-Ramos and Marsh, unpublished results), suggesting that the steady-state levels of cell surface US28 are maintained through recycling rather than delivery of newly synthesized US28 to the plasma membrane.

Recycling of US28 could also be demonstrated directly. HeLa CD4-US28 cells were incubated with Q4120 for $1 \mathrm{~h}$ at $37^{\circ} \mathrm{C}$, to allow antibody uptake, and then cooled on ice and acid washed to remove antibody remaining at the cell surface. Figure $8 \mathrm{~A}$ shows that the antibody was internalized, as indicated by the intracellular staining, and that there was no antibody remaining at the cell surface after the acid wash. A second set of cells was treated similarly but then reincubated with a biotin-coupled secondary antibody against mouse $\operatorname{IgG}$ for $1 \mathrm{~h}$ at $37^{\circ} \mathrm{C}$. If the US28-antibody complex recycled to the cell surface, the secondary antibody would be internalized. After the second incubation, the cells were transferred to ice, acid washed, and stained with fluorescein-streptavidin. As shown in Figure 8B, intracellular vesicular staining indicated that the secondary antibody was internalized, supporting the notion that US28 undergoes constitutive endocytosis and recycling even when conjugated with an antiCD4 antibody. Cells that were not incubated with primary antibodies showed no fluorescence, indicating that the labeling was dependent on US28-antibody complex-mediated uptake of the secondary antibody.

\section{Fractalkine Down-Modulates US28}

Fractalkine has been identified as the preferred ligand for US28 and can modulate the constitutive signaling of this molecule (Casarosa et al., 2001; Kledal et al., 1998; T. Kledal 

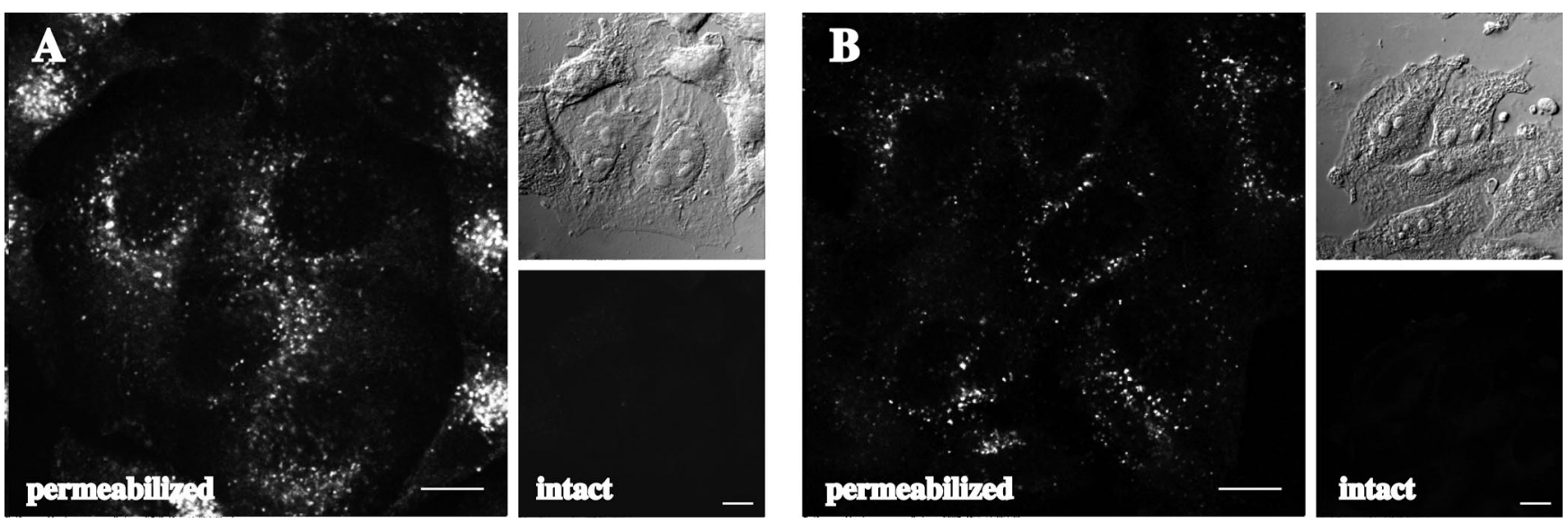

Figure 8. Recycling of US28. HeLa CD4-US28 cells were incubated with Q4120 antibody at $37^{\circ} \mathrm{C}$ for $1 \mathrm{~h}$ to allow antibody uptake, cooled on ice, and washed in acid medium to remove the Q4120 bound to the cell surface. (A) The cells were fixed, left intact or permeabilized with saponin (right and left, respectively), and then stained with a biotin-conjugated secondary antibody to detect Q4120 followed by fluoresceinstreptavidin. (B) The cells were reincubated with a biotin-conjugated secondary antibody for $1 \mathrm{~h}$ at $37^{\circ} \mathrm{C}$, cooled on ice, acid washed, fixed, and stained with fluorescein-streptavidin as in A. Scale bars, $10 \mu \mathrm{m}$. The righthand fields for each panel show Nomarski and fluorescence images of the same field.

and T. Schwartz, unpublished data). We investigated whether fractalkine could induce endocytosis of its receptor by using CD4-US28, ${ }^{125} \mathrm{I}-\mathrm{Q} 4120$, and prebound unlabeled fractalkine. To test the preparation of fractalkine we first determined its ability to compete with ${ }^{125}$ I-RANTES for binding. HeLa CD4-US28 cells were incubated with 125 pM ${ }^{125}$ I-RANTES in the presence of increasing concentrations of fractalkine for $2 \mathrm{~h}$ at $4^{\circ} \mathrm{C}$ and washed, and the associated radioactivity was determined. ${ }^{125}$ I-RANTES binding was reduced $\sim 50 \%$ with $0.5 \mathrm{nM}$ fractalkine and $\sim 90 \%$ with 100 nM fractalkine, as previously observed (Kledal et al., 1998). In addition, control experiments demonstrated that fractalkine did not compete with ${ }^{125} \mathrm{I}-\mathrm{Q} 4120$ for binding to CD4US28. Similar levels of Q4120 binding were observed on HeLa CD4-US28 cells treated with $100 \mathrm{nM}$ fractalkine or on untreated cells (Fraile-Ramos and Marsh, unpublished results).

To determine whether fractalkine induced endocytosis of US28, HeLa CD4-US28 cells were labeled with ${ }^{125} \mathrm{I}-\mathrm{Q} 4120$ and $100 \mathrm{nM}$ fractalkine for $2 \mathrm{~h}$ at $4^{\circ} \mathrm{C}$, washed, and then warmed to $37^{\circ} \mathrm{C}$. The amount of internalized ligand was determined by acid washing, as described above. CD4-US28 underwent rapid endocytosis in the presence of fractalkine. However, the kinetics of uptake were identical to those observed in its absence, and they were almost identical to those observed in the presence of RANTES (Figure 9), indicating that prebinding of fractalkine did not influence the constitutive endocytosis of US28.

Finally, we investigated whether fractalkine can induce down-modulation of its receptor. HeLa CD4-US28 cells were incubated in $100 \mathrm{nM}$ fractalkine for up to $30 \mathrm{~min}$, transferred to ice, washed, and labeled with ${ }^{125} \mathrm{I}-\mathrm{Q} 4120$ to measure the level of receptor at the cell surface. Figure 7B shows that incubation in fractalkine induced some down-modulation of cell surface US28 (25\% in $30 \mathrm{~min})$. The levels of cell surface US28 continued to decrease with prolonged incubations, with $60 \%$ of the initial levels remaining by $2 \mathrm{~h}$ of treatment. Together these results indicate that fractalkine does not in- fluence the rapid endocytosis of US28 and that the observed down-modulation of US28 by this ligand may be due to an inhibition of recycling.

\section{DISCUSSION}

The HCMV genome contains four ORFs with the potential to encode proteins with homology to 7TM GPCRs, namely, UL33, UL78, US27, and US28 (Chee et al., 1990; Gompels et al., 1995). UL33 and US28 transcripts can be detected at early

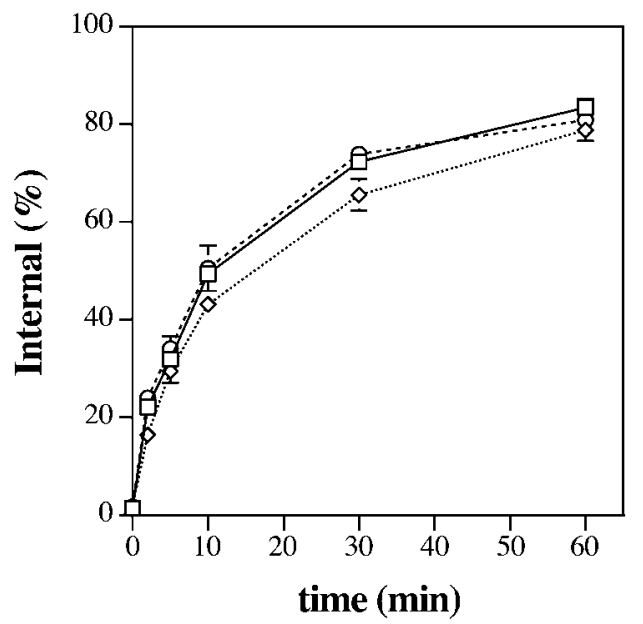

Figure 9. Endocytosis of US28 in the presence of ligands. HeLa CD4-US28 cells were labeled with ${ }^{125} \mathrm{I}-\mathrm{Q} 4120$ in medium $(\square)$, medium containing $100 \mathrm{nM}$ RANTES $(\diamond)$, or $100 \mathrm{nM}$ fractalkine $(\bigcirc)$ for $2 \mathrm{~h}$ at $4^{\circ} \mathrm{C}$, washed, and then warmed to $37^{\circ} \mathrm{C}$. The amount of internalized antibody was determined by acid wash. All data points show means and SDs for duplicate samples from a representative experiment. 

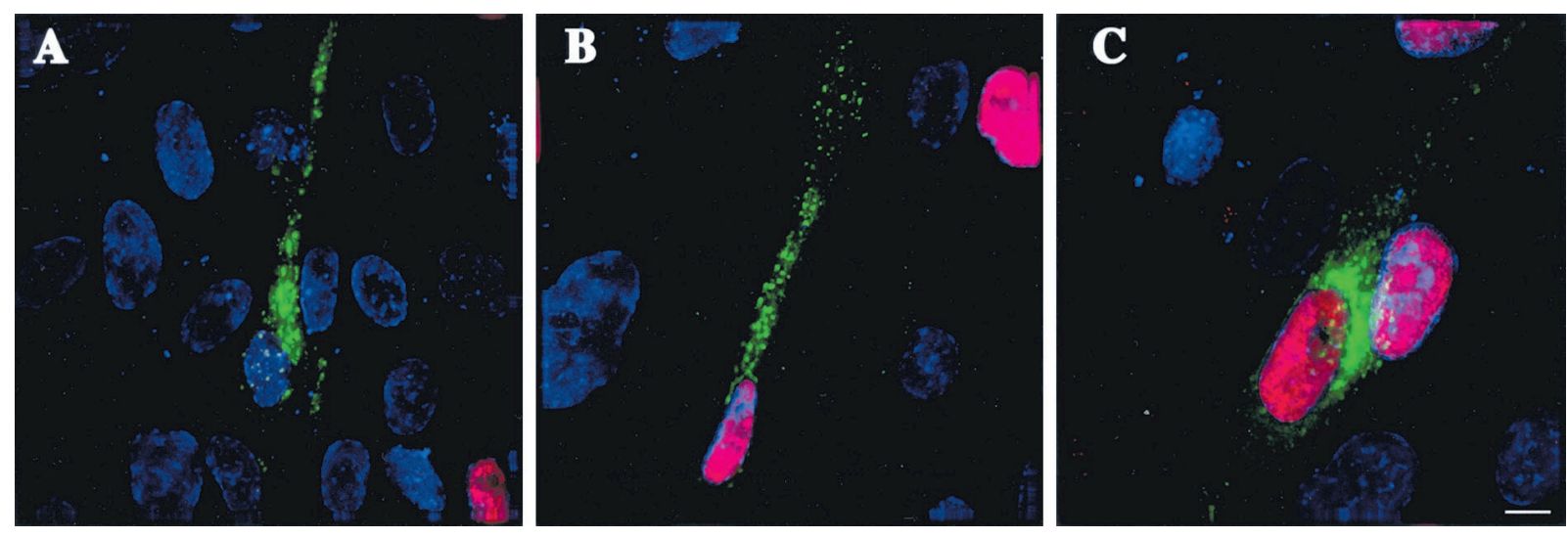

Figure 10. Intracellular localization of US28 in HCMV-infected fibroblasts. Localization of US28-YFP in transiently transfected human foreskin fibroblasts, infected with the Towne strain of HCMV. Antibody against HCMV IE1 used to detect HCMV infected cells is seen as red nuclear staining. Hoechst staining of all nuclei is seen in blue. (A-C) US28-YFP (green) is seen as mainly punctate intracellular staining in both uninfected (A) and HCMV-infected fibroblasts at both $24 \mathrm{~h}$ (B) and $48 \mathrm{~h}$ (C) postinfection. Scale bar, $10 \mu \mathrm{m}$.

and late times after infection, but US27 is detected only at late times postinfection (Welch et al., 1991; Bodaghi et al., 1998; Vieira et al., 1998; Zipeto et al., 1999). Very little is known about UL78. Although homologues have been found in both mouse and rat CMVs, the function of these proteins remains unclear. Knockout studies indicate that these proteins are not essential for viral replication in culture but may have some role in viral tropism in vivo (Davis-Poynter et al., 1997; Beisser et al., 1998). US28 binds chemokines and has been proposed to modulate anti-CMV immune responses by clearing host chemokines from the environment around infected cells (Bodaghi et al., 1998; Vieira et al., 1998). In addition, the suggestion that these proteins are incorporated into the viral membrane may also indicate some role in cell-cell transmission (Margulies et al., 1996; Kledal et al., 1998). Here we have studied the cellular distribution and trafficking of US28, with a view to better understanding the function of this protein in HCMV replication.

When expressed in the absence of other HCMV proteins, tagged US28 molecules were located mostly intracellularly. We attempted to identify this localization with the use of markers for various cellular compartments. This demonstrated a significant overlap with markers for early endosomes and late endosomes/lysosomes, suggesting that this viral protein is located at least in part in the endocytic pathway. We also studied the distribution of US28-GFP by EM of immunogold labeled ultrathin frozen sections. The protein was seen to be associated with multivesicular bodies that have the characteristics of late endosomes and can be labeled with antibodies to the late endosome markers CD63 and lyso bis-phosphatidic acid (Kobayashi et al., 1998). Labeling of US28-GFP was seen on both the limiting membrane of these structures and on the internal vesicles. In addition, US28-GFP was located to some extent at the plasma membrane and in small tubules and vesicles that could correspond to early endosomes. Although we have not yet been able to observe native US28, we have no evidence that the tags applied to the molecules used here significantly affect the distribution of the protein. Molecules tagged in both the cytoplasmic C-terminal domain and in the extracellular Nterminal domain showed an identical cellular distribution.
Moreover, both long (CD4 domains 1 and 2) and short (HA-epitope) N-terminally tagged US28 molecules have indistinguishable properties. Together, these observations indicate that US28 is located primarily in endosomal organelles. This distribution is markedly different from most cellular chemokine receptors, which frequently appear at the cell surface (Amara et al., 1997; Signoret et al., 1997). Redistribution of these receptors to endosomes occurs only when expressing cells are bound by agonists (Amara et al., 1997; Signoret et al., 1997). In addition, the distribution of US28 is distinct from that of another viral chemokine receptor, ORF74 from human herpesvirus 8 , which is located at the cell surface (A. Fraile-Ramos, T.W. Schwartz and M. Marsh, unpublished observation).

The distribution we describe for US28 is based on transient and stable expression of tagged-proteins in the absence of other viral transcripts and illustrates the intrinsic trafficking properties of the protein. Whether this reflects the properties of US28 in HCMV-infected cells is currently unclear. Infection by HCMV, like that of a number of other viruses, may interfere with trafficking of cellular proteins or with the organization of cellular compartments (Fish et al., 1996; Sanchez et al., 2000a). Moreover, the interaction with tegument components might influence the sorting properties of viral envelope proteins (Sanchez et al., 2000b). However, when US28-YFP was expressed in human foreskin fibroblasts and these cells were then infected with HCMV, the distribution of US28-YFP at 24 and $48 \mathrm{~h}$ postinfection was similar to that seen in uninfected cells (Figure 10). Thus, US28 may also be located in endocytic compartments in HCMV-infected cells.

Although US28 is mostly intracellular, it is also found on the surface of both transfected (Pleskoff et al., 1998; Streblow et al., 1999; Ohagen et al., 2000) and HCMV-infected cells (Michelson et al., 1997; Billstrom et al., 1998; Bodaghi et al., 1998; Vieira et al., 1998). We found that this cell surface US28 undergoes rapid constitutive endocytosis and recycling. The rate of internalization was $\sim 7 \%$ of the cell surface pool per minute, and after 60 min up to $90 \%$ of the initial surface pool was intracellular. These internalization properties are similar to those of activated chemokine receptors. We previously 
demonstrated that both phorbol esters and SDF-1 induce endocytosis of the cellular chemokine receptor CXCR4 (Signoret et al., 1997). The kinetics of US28 endocytosis were similar to those seen for SDF-1-induced internalization of CXCR4 and significantly faster than phorbol ester-induced uptake. The rapid endocytosis of US28 was not affected by the ligand RANTES or by binding of the bivalent tracer antibody Q4120, which has the potential to cross-link US28 receptors. The fact that cells maintain a constant level of US28 at the cell surface, while constitutive endocytosis occurs, suggests that internalized US28 is recycled. Cycloheximide treatment did not significantly deplete cell surface US28. Moreover, recycling could be demonstrated directly in antibody-feeding experiments. Interestingly, antibody molecules internalized on CD4-US28 can be seen in multivesicular endosomes by immunolabeling cryosections of antibody-treated CD4-US28 cells (A. Fraile-Ramos, A. PelchenMatthews and M. Marsh, unpublished observations), suggesting that the multivesicular body pool of US28 may be part of the recycling itinerary. In this respect the recycling pathway of US28 may be similar to that described for the lysosomal tetraspanin CD63, which is also found on the internal membranes of multivesicular bodies but is able to recycle via the plasma membrane (Arribas and Cutler, 2000; Kobayashi et al., 2000). Whether most of the newly synthesized US28 is delivered to the plasma membrane and then internalized, or whether the protein is directly targeted to endosomal compartments and then cycles to the cell surface, is not yet established.

We have previously shown that US28 binds fractalkine with high affinity (Kledal et al., 1998) and that fractalkine partially inhibits the constitutive activity of US28 (Casarosa et al., 2001; T. Kledal and T. Schwartz, unpublished data). Here we found that the isolated extracellular domain of fractalkine can induce some down-modulation of cell surface US28. Fractalkine did not affect the kinetics of US28 endocytosis, suggesting that down-modulation may be due to an inhibition of US28 recycling. The fact that fractalkine only partially inhibits US28 signaling may be a consequence of the cellular distribution of the protein, with only a portion of the receptor being available for ligand binding.

It was previously shown that US28 internalizes extracellular chemokines, suggesting that this viral chemokine receptor may be able to sequester CC-chemokines from the environment of HCMV-infected cells (Bodaghi et al., 1998; Vieira et al., 1998). Here we demonstrated directly that ${ }^{125} \mathrm{I}-$ RANTES is also rapidly internalized. Constitutive endocytosis will probably occur for any ligand that binds US28. Once internalized, the ligand may dissociate from the receptor in early or late endosomes and eventually be degraded. The Duffy antigen receptor for chemokines (DARC) has been shown to be a promiscuous receptor that binds both CXC and CC-chemokines with high affinity. DARC is expressed on red blood cells, endothelial cells of postcapillary venules, and Purkinje cells of the cerebellum (Hadley and Peiper, 1997). Although DARC on red blood cells does not internalize, there is evidence that DARC-transfected nonerythroid cells can internalize chemokines (Peiper et al., 1995). The physiological role of this chemokine receptor is not clearly defined, but it has been postulated that DARC also acts as a sink or clearance mechanism for the chemokines that it binds (Darbonne et al., 1991). Whether DARC is internalized and recycled in a manner similar to that described here for US28 remains to be determined.

The molecular mechanisms of US28 endocytosis and intracellular trafficking remain to be elucidated. Clathrin-mediated endocytosis has been implicated in the internalization of some cellular GPCRs (Lin et al., 1998). This internalization is dependent on phosphorylation of serine residues in the cytoplasmic tail of the receptor and at least in some cases involves interaction with nonvisual arrestins (Ferguson et al., 1996; Goodman et al., 1996). US28 has a Ser-rich Cterminal domain, and we have occasionally seen US28 in coated pits on immunolabeled cryosections. Our kinetic data indicate that the properties of US28 endocytosis are similar to those of an agonist-treated GPCR; however, it remains unclear whether the clathrin-mediated route is the principal pathway for US28 uptake, whether arrestins play a role, or whether US28 is phosphorylated.

The assembly of HCMV particles is a complex and poorly understood process. One model proposes that the viral core is assembled in the nucleus of the infected cell and is then released into the cytoplasm. This release involves budding through the inner nuclear membrane and fusion with the outer nuclear/endoplasmic reticulum membrane. In the cytoplasm the core associates with proteins that form the tegument and then buds through a membrane system into the lumen of an as yet poorly characterized compartment. Various locations have been proposed for the final step in herpes virus envelopment including Golgi and post-Golgi membranes (Browne et al., 1996; Whiteley et al., 1999). Previous EM studies of HCMV assembly showed viral particles budding into cytoplasmic vacuoles including multivesicular bodies (Smith and De Harven, 1973), and it has been proposed that the HCMV particles can be wrapped by endosomal membranes (Tooze et al., 1993). Importantly, the HCMV 7TM protein UL33 has also been found to accumulate intracellularly in the perinuclear region of the infected cell (Margulies et al., 1996), and both UL33 and US27 have been found to be incorporated into the viral envelope (Margulies et al., 1996; H. Browne perssonal communication). Because there are as yet no antibodies available against US28 it has not been possible to demonstrate that this protein is incorporated into the viral envelope. However, we have located UL33 and US27 in endosomal membranes by immunofluorescence. When US27 and US28 were coexpressed, their distributions showed a significant overlap and UL33 was also seen to localize to multivesicular endosomes by EM (A. Fraile-Ramos, A. Pelchen-Matthews, T. W. Schwartz and M. Marsh, unpublished observations). Together these observations suggest that the localization of UL33, US27, and US28 to endosomes may allow these proteins to be incorporated into the viral membrane during the final stages of HCMV assembly. This viral US28 may have some propensity to bind fractalkine on target cells (Kledal et al., 1998) and would be inserted into the plasma membrane of the target cell after fusion. Whether this protein is responsible for cellular changes associated with G protein signaling (Albrecht et al., 1990) remains to be established. The possibility that other proteins, including the viral glycoproteins involved in fusion and entry, are located on endocytic membranes also remains to be established. 


\section{ACKNOWLEDGMENTS}

We are grateful to colleagues who have contributed reagents, ideas, and discussion to this work. In particular, we thank Dr. M.-J. Bijlmakers for critically reading the manuscript and Dr. N. Signoret for help with the CCR5 down-modulation studies. A. Fraile-Ramos, A. Pelchen-Matthews, K. Bowers, and M. Marsh were supported by grants from the United Kingdom Medical Research Council. T.N. Kledal and T.W. Schwartz were supported by grants from the Danish Medical Research Council.

\section{REFERENCES}

Agard, D.A., and Sedat, J.W. (1983). Three-dimensional architecture of a polytene nucleus. Nature 302, 676-681.

Ahuja, S.K., and Murphy, P.M. (1993). Molecular piracy of mammalian interleukin-8 receptor type B by herpesvirus saimiri. J. Biol. Chem. 268, 20691-20694.

Albrecht, T., Boldogh, I., Fons, M., AbuBakar, S., and Deng, C.Z. (1990). Cell activation signals and the pathogenesis of human cytomegalovirus. Intervirology 31, 68-75.

Amara, A., LeGall, S., Schwartz, O., Salamero, J., Montes, M., Loetscher, P., Baggiolini, M., Virelizier, J.L., and ArenzanaSeisdedos, F. (1997). HIV coreceptor downregulation as antiviral principle: SDF-1 alpha- dependent internalization of the chemokine receptor CXCR4 contributes to inhibition of HIV replication. J. Exp. Med. 186, 139-146.

Arribas, M., and Cutler, D.F. (2000). Weibel-Palade body membrane proteins exhibit differential trafficking after exocytosis in endothelial cells. Traffic 1, 783-793.

Arvanitakis, L., Geras-Raaka, E., Varma, A., Gershengorn, M.C., and Cesarman, E. (1997). Human herpesvirus KSHV encodes a constitutively active G-protein-coupled receptor linked to cell proliferation. Nature 385, 347-350.

Beisser, P.S., Vink, C., Van Dam, J.G., Grauls, G., Vanherle, S.J., and Bruggeman, C.A. (1998). The R33 G protein-coupled receptor gene of rat cytomegalovirus plays an essential role in the pathogenesis of viral infection. J. Virol. 72, 2352-2363.

Billstrom, M.A., Johnson, G.L., Avdi, N.J., and Worthen, G.S. (1998). Intracellular signaling by the chemokine receptor US28 during human cytomegalovirus infection. J. Virol. 72, 5535-5544.

Bodaghi, B., Jones, T.R., Zipeto, D., Vita, C., Sun, L., Laurent, L., Arenzana-Seisdedos, F., Virelizier, J.L., and Michelson, S. (1998). Chemokine sequestration by viral chemoreceptors as a novel viral escape strategy: withdrawal of chemokines from the environment of cytomegalovirus-infected cells. J. Exp. Med. 188, 855-866.

Browne, H., Bell, S., Minson, T., and Wilson, D.W. (1996). An endoplasmic reticulum-retained herpes simplex virus glycoprotein $\mathrm{H}$ is absent from secreted virions: evidence for reenvelopment during egress. J. Virol. 70, 4311-4316.

Casarosa, P., Bakker, R.A., Verzijl, D., Navis, M., Timmerman, H., Leurs, R., and Smit, M.J. (2001). Constitutive signaling of the human cytomegalovirus-encoded chemokine receptor US28. J. Biol. Chem. 267, 1133-1137.

Cesarman, E., Nador, R.G., Bai, F., Bohenzky, R.A., Russo, J.J., Moore, P.S., Chang, Y., and Knowles, D.M. (1996). Kaposi's sarcoma-associated herpesvirus contains $G$ protein-coupled receptor and cyclin D homologs which are expressed in Kaposi's sarcoma and malignant lymphoma. J. Virol. 70, 8218-8223.

Chee, M.S., Satchwell, S.C., Preddie, E., Weston, K.M., and Barrell, B.G. (1990). Human cytomegalovirus encodes three G protein-coupled receptor homologues. Nature 344, 774-777.
Darbonne, W.C., Rice, G.C., Mohler, M.A., Apple, T., Hebert, C.A., Valente, A.J., and Baker, J.B. (1991). Red blood cells are a sink for interleukin 8, a leukocyte chemotaxin. J. Clin. Invest. 88, 1362-1369.

Davis-Poynter, N.J., Lynch, D.M., Vally, H., Shellam, G.R., Rawlinson, W.D., Barrell, B.G., and Farrell, H.E. (1997). Identification and characterization of a $G$ protein-coupled receptor homolog encoded by murine cytomegalovirus. J. Virol. 71, 1521-1529.

Endres, M.J., Clapham, P.R., Marsh, M., Ahuja, M., Turner, J.D., McKnight, A., Thomas, J.F., Stoebenau-Haggarty, B., Choe, S., Vance, P.J., Wells, T.N., Power, C.A., Sutterwala, S.S., Doms, R.W., Landau, N.R., and Hoxie, J.A. (1996). CD4-independent infection by HIV-2 is mediated by fusin/CXCR4. Cell 87, 745-756.

Ferguson, S.S., Barak, L.S., Zhang, J., and Caron, M.G. (1996). Gprotein-coupled receptor regulation: role of G-protein-coupled receptor kinases and arrestins. Can. J. Physiol. Pharmacol. 74, 10951110.

Fish, K.N., Britt, W., and Nelson, J.A. (1996). A novel mechanism for persistence of human cytomegalovirus in macrophages. J. Virol. 70, $1855-1862$.

Futter, C.E., Gibson, A., Allchin, E.H., Maxwell, S., Ruddock, L.J., Odorizzi, G., Domingo, D., Trowbridge, I.S., and Hopkins, C.R. (1998). In polarized MDCK cells basolateral vesicles arise from clathrin-gamma-adaptin-coated domains on endosomal tubules. J. Cell Biol. 141, 611-623.

Gao, J.L., and Murphy, P.M. (1994). Human cytomegalovirus open reading frame US28 encodes a functional beta chemokine receptor. J. Biol. Chem. 269, 28539-28542.

Gompels, U.A., Nicholas, J., Lawrence, G., Jones, M., Thomson, B.J., Martin, M.E., Efstathiou, S., Craxton, M., and Macaulay, H.A. (1995). The DNA sequence of human herpesvirus-6: structure, coding content, and genome evolution. Virology 209, 29-51.

Goodman, O.B., Jr., Krupnick, J.G., Santini, F., Gurevich, V.V., Penn, R.B., Gagnon, A.W., Keen, J.H., and Benovic, J.L. (1996). Beta-arrestin acts as a clathrin adaptor in endocytosis of the beta2-adrenergic receptor. Nature $383,447-450$.

Grulher, A., and Früh, K. (2000). Control of MHC class I traffic from the endoplasmic reticulum by cellular chaperones and viral antichaperones. Traffic 1, 306-311.

Hadley, T.J., and Peiper, S.C. (1997). From malaria to chemokine receptor: the emerging physiologic role of the Duffy blood group antigen. Blood 89, 3077-3091.

Healey, D., Dianda, L., Moore, J.P., McDougal, J.S., Moore, M.J., Estess, P., Buck, D., Kwong, P.D., Beverley, P.C., and Sattentau, Q.J. (1990). Novel anti-CD4 monoclonal antibodies separate human immunodeficiency virus infection and fusion of CD4+ cells from virus binding. J. Exp. Med. 172, 1233-1242.

Isegawa, Y., Ping, Z., Nakano, K., Sugimoto, N., and Yamanishi, K. (1998). Human herpesvirus 6 open reading frame U12 encodes a functional beta-chemokine receptor. J. Virol. 72, 6104-6112.

Johansen, T.E., Scholler, M.S., Tolstoy, S., and Schwartz, T.W. (1990). Biosynthesis of peptide precursors and protease inhibitors using new constitutive and inducible eukaryotic expression vectors. FEBS Lett. 267, 289-294.

Klasse, P.J., Rosenkilde, M.M., Signoret, N., Pelchen-Matthews, A., Schwartz, T.W., and Marsh, M. (1999). CD4-chemokine receptor hybrids in human immunodeficiency virus type 1 infection. J. Virol. 73, 7453-7466.

Kledal, T.N., Rosenkilde, M.M., and Schwartz, T.W. (1998). Selective recognition of the membrane-bound $\mathrm{CX} 3 \mathrm{C}$ chemokine, fractalkine, by the human cytomegalovirus-encoded broad-spectrum receptor US28. FEBS Lett. 441, 209-214. 
Kobayashi, T., Stang, E., Fang, K.S., de Moerloose, P., Parton, R.G., and Gruenberg, J. (1998). A lipid associated with the antiphospholipid syndrome regulates endosome structure and function. Nature 392, 193-197.

Kobayashi, T., Vischer, U.M., Rosnoblet, C., Lebrand, C., Lindsay, M., Parton, R.G., Kruithof, E.K., and Gruenberg, J. (2000). The tetraspanin CD63/lamp3 cycles between endocytic and secretory compartments in human endothelial cells. Mol. Biol. Cell 11, 1829-1843.

Kuhn, D.E., Beall, C.J., and Kolattukudy, P.E. (1995). The cytomegalovirus US28 protein binds multiple CC chemokines with high affinity. Biochem. Biophys. Res. Commun. 211, 325-330.

Lin, F.T., Daaka, Y., and Lefkowitz, R.J. (1998). $\beta$-Arrestins regulate mitogenic signaling and clathrin-mediated endocytosis of the insulin-like growth factor I receptor. J. Biol. Chem. 273, 31640-31643.

Mack, M., Luckow, B., Nelson, P.J., Cihak, J., Simmons, G., Clapham, P.R., Signoret, N., Marsh, M., Stangassinger, M., Borlat, F., Wells, T.N., Schlondorff, D., and Proudfoot, A.E. (1998). Aminooxypentane-RANTES induces CCR5 internalization but inhibits recycling: a novel inhibitory mechanism of HIV infectivity. J. Exp. Med. 187, 1215-1224.

Margulies, B.J., Browne, H., and Gibson, W. (1996). Identification of the human cytomegalovirus $\mathrm{G}$ protein-coupled receptor homologue encoded by UL33 in infected cells and enveloped virus particles. Virology 225, 111-125.

Michelson, S., Dal Monte, P., Zipeto, D., Bodaghi, B., Laurent, L., Oberlin, E., Arenzana-Seisdedos, F., Virelizier, J.L., and Landini, M.P. (1997). Modulation of RANTES production by human cytomegalovirus infection of fibroblasts. J. Virol. 71, 6495-6500.

Milne, R.S., Mattick, C., Nicholson, L., Devaraj, P., Alcami, A., and Gompels, U.A. (2000). RANTES binding and down-regulation by a novel human herpesvirus- 6 beta chemokine receptor. J. Immunol. $164,2396-2404$.

Mocarski, E.S., Jr., and Kemble, G.W. (1996). Recombinant cytomegaloviruses for study of replication and pathogenesis. Intervirology 39, 320-330.

Murphy, P.M., Baggiolini, M., Charo, I.F., Hebert, C.A., Horuk, R., Matsushima, K., Miller, L.H., Oppenheim, J.J., and Power, C.A. (2000). International union of pharmacology. XXII. Nomenclature for chemokine receptors. Pharmacol. Rev. 52, 145-176.

Neote, K., DiGregorio, D., Mak, J.Y., Horuk, R., and Schall, T.J. (1993). Molecular cloning, functional expression, and signaling characteristics of a C-C chemokine receptor. Cell 72, 415-425.

Ohagen, A., Li, L., Rosenzweig, A., and Gabuzda, D. (2000). Celldependent mechanisms restrict the HIV type 1 coreceptor activity of US28, a chemokine receptor homolog encoded by human cytomegalovirus. AIDS Res. Hum. Retroviruses 16, 27-35.

Peiper, S.C., Wang, Z.X., Neote, K., Martin, A.W., Showell, H.J., Conklyn, M.J., Ogborne, K., Hadley, T.J., Lu, Z.H., and Hesselgesser, J., et al. (1995). The Duffy antigen/receptor for chemokines (DARC) is expressed in endothelial cells of Duffy negative individuals who lack the erythrocyte receptor. J. Exp. Med. 181, 1311-1317.

Pelchen-Matthews, A., Armes, J.E., Griffiths, G., and Marsh, M. (1991). Differential endocytosis of CD4 in lymphocytic and nonlymphocytic cells. J. Exp. Med. 173, 575-587.
Pelchen-Matthews, A., Signoret, N., Klasse, P.J., Fraile-Ramos, A., and Marsh, M. (1999). Chemokine receptor trafficking and viral replication. Immunol. Rev. 168, 33-49.

Pleskoff, O., Treboute, C., and Alizon, M. (1998). The cytomegalovirus-encoded chemokine receptor US28 can enhance cell-cell fusion mediated by different viral proteins. J. Virol. 72, 6389-6397.

Proudfoot, A.E., Power, C.A., Hoogewerf, A.J., Montjovent, M.O., Borlat, F., Offord, R.E., and Wells, T.N. (1996). Extension of recombinant human RANTES by the retention of the initiating methionine produces a potent antagonist. J. Biol. Chem. 271, 2599-2603.

Raposo, G., Kleijmeer, M.J., Posthuma, G., Slot, J.W., and Geuze, H.J. (1997). Immunogold labeling of ultrathin cryosections: Application in immunology. In: Handbook of Experimental immunology, vol. 4, chap. 208, L.A. Herzenberg, D.M. Weir, L.A. Herzenberg, and C. Blackwell, eds. Oxford, UK: Blackwell Science, 201-211.

Sanchez, V., Greis, K.D., Sztul, E., and Britt, W.J. (2000a). Accumulation of virion tegument and envelope proteins in a stable cytoplasmic compartment during human cytomegalovirus replication: characterization of a potential site of virus assembly. J. Virol. 74, 975-986.

Sanchez, V., Sztul, E., and Britt, W.J. (2000b). Human cytomegalovirus pp28 (UL99) localizes to a cytoplasmic compartment which overlaps the endoplasmic reticulum-Golgi-intermediate compartment. J. Virol. 74, 3842-3851.

Signoret, N.,Oldridge, J., Pelchen-Matthews, A., Klasse, P.J., Tran, T., Brass, L.F., Rosenkilde, M.M., Schwartz, T.W., Holmes, W., Dallas, W., Luther, M.A., Wells, T.N., Hoxie, J.A., and Marsh, M. (1997). Phorbol esters and SDF-1 induce rapid endocytosis and down modulation of the chemokine receptor CXCR4. J. Cell Biol. 139, 651-664.

Signoret, N., Pelchen-Matthews, A., Mack, M., Proudfoot, A.E., and Marsh, M. (2000). Endocytosis and recycling of the HIV co-receptor CCR5. J. Cell Biol. 151, 1281-1294.

Smith, J.D., and De Harven, E. (1973). Herpes simplex virus and human cytomegalovirus replication in WI-38 cells. I. Sequence of viral replication. J. Virol. 12, 919-930.

Streblow, D.N., Soderberg-Naucler, C., Vieira, J., Smith, P., Wakabayashi, E., Ruchti, F., Mattison, K., Altschuler, Y., and Nelson, J.A. (1999). The human cytomegalovirus chemokine receptor US28 mediates vascular smooth muscle cell migration. Cell 99, 511-520.

Tooze, J., Hollinshead, M., Reis, B., Radsak, K., and Kern, H. (1993). Progeny vaccinia and human cytomegalovirus particles utilize early endosomal cisternae for their envelopes. Eur. J. Cell. Biol. 60, 163178.

Vieira, J., Schall, T.J., Corey, L., and Geballe, A.P. (1998). Functional analysis of the human cytomegalovirus US28 gene by insertion mutagenesis with the green fluorescent protein gene. J. Virol. 72, $8158-8165$.

Welch, A.R., McGregor, L.M., and Gibson, W. (1991). Cytomegalovirus homologs of cellular $G$ protein-coupled receptor genes are transcribed. J. Virol. 65, 3915-3918.

Whiteley, A., Bruun, B., Minson, T., and Browne, H. (1999). Effects of targeting herpes simplex virus type $1 \mathrm{gD}$ to the endoplasmic reticulum and trans-Golgi network. J. Virol. 73, 9515-9520.

Zipeto, D., Bodaghi, B., Laurent, L., Virelizier, J.L., and Michelson, S. (1999). Kinetics of transcription of human cytomegalovirus chemokine receptor US28 in different cell types. J. Gen. Virol. 80, 543-547. 